San Jose State University

SJSU ScholarWorks

Master's Theses

Master's Theses and Graduate Research

1992

\title{
The effect of creating and writing word problems on first and fourth grade students' abililty to solve word problems
}

Mary V. Finkas

San Jose State University

Follow this and additional works at: https://scholarworks.sjsu.edu/etd_theses

\section{Recommended Citation}

Finkas, Mary V., "The effect of creating and writing word problems on first and fourth grade students' abililty to solve word problems" (1992). Master's Theses. 280.

DOI: https://doi.org/10.31979/etd.zgfb-e7xw

https://scholarworks.sjsu.edu/etd_theses/280

This Thesis is brought to you for free and open access by the Master's Theses and Graduate Research at SJSU ScholarWorks. It has been accepted for inclusion in Master's Theses by an authorized administrator of SJSU ScholarWorks. For more information, please contact scholarworks@sjsu.edu. 


\section{INFORMATION TO USERS}

This manuscript has been reproduced from the microfilm master. UMI films the text directly from the original or copy submitted. Thus, some thesis and dissertation copies are in typewriter face, while others may be from any type of computer printer.

The quality of this reproduction is dependent upon the quality of the copy submitted. Broken or indistinct print, colored or poor quality illustrations and photographs, print bleedthrough, substandard margins, and improper alignment can adversely affect reproduction.

In the unlikely event that the author did not send UMI a complete manuscript and there are missing pages, these will be noted. Also, if unauthorized copyright material had to be removed, a note will indicate the deletion.

Oversize materials (e.g., maps, drawings, charts) are reproduced by sectioning the original, beginning at the upper left-hand corner and continuing from left to right in equal sections with small overlaps. Each original is also photographed in one exposure and is included in reduced form at the back of the book.

Photographs included in the original manuscript have been reproduced xerographically in this copy. Higher quality $6^{\prime \prime} \times 9^{\prime \prime}$ black and white photographic prints are available for any photographs or illustrations appearing in this copy for an additional charge. Contact UMI directly to order.

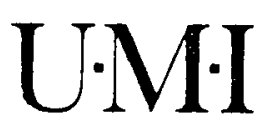

University Microfilms International

A Bell \& Howell Information Company 
Order Number 1348206

The effect of creating and writing word problems on first and fourth grade students' ability to solve word problems

Finkas, Mary V., M.A.

San Iose State University, 1992

Copyright $@ 1992$ by Finkas, Mary V. All rights reserved.

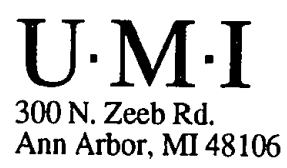


THE EFFECT OF CREATING AND WRITING WORD PROBLEMS

ON FIRST AND FOURTH GRADE STUDENTS' ABILITY

TO SOLVE WORD PROBLEMS

\author{
A Thesis \\ Presented to \\ The Faculty of the school of Education \\ San Jose State University
}

In Partial Fulfillment

of the Requirements for the Degree

Master of Arts

By

Mary V. Finkas

May, 1992 


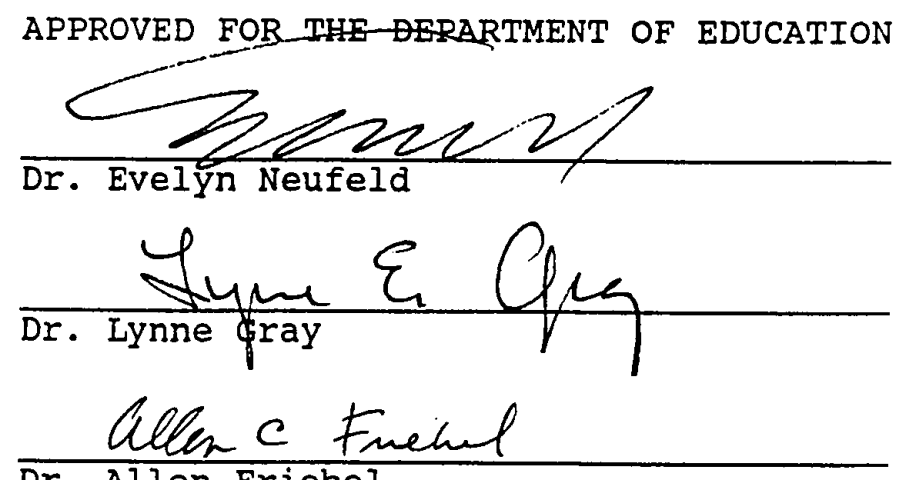
Dr. Allen Friebel

APPROVED FOR THE UNIVERSITY

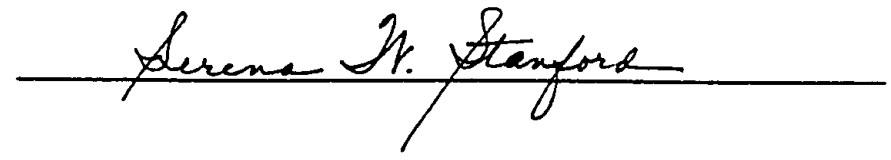




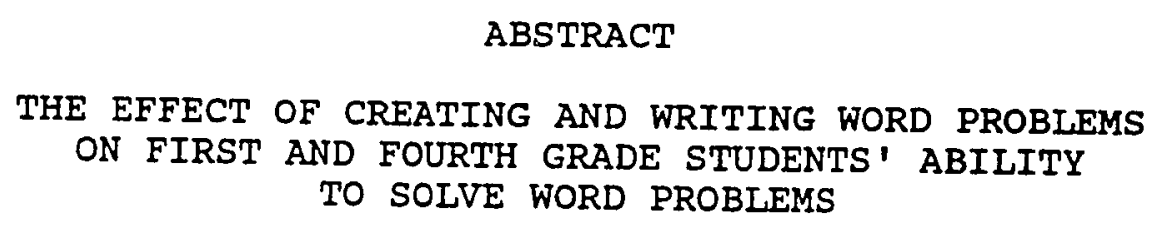

by Mary V. Finkas

Fifty-nine students in the first and fourth grade were the subjects for this study. One group of first grade students and one group of fourth grade students were asked to create and write their own word problems over a twelve week period of time. One group of first grade students and one group of fourth grade students served as control groups who were taught to solve word problems through the standard California textbook method. It was hypothesized that if subjects created and wrote their own word problems they would be better able to solve standard word problems than children who had been taught to solve word problems through the standard California textbook method. Results indicated that all subjects' performance in solving standard word problems improved by the end of the treatment; however, the treatment groups' increases were greater. This gain did not prove to be statistically significant. 
Page

LIST OF TABLES . . . . . . . . . . . . . . . . . . . . vi vi

LIST OF FIGURES. . . . . . . . . . . . . . . . . . . vii v vi Chapter

I. Introduction. . . . . . . . . . . . . 1

Background. . . . . . . . . . . 2

Statement of Purpose. . . . . . . 10

Hypotheses. . . . . . . . . . 10

II. Review of the Literature. . . . . . . . 11

Previous Research on Word Problems. . . . 11

Strategies to Improve Students'

Performance on Word Problems . . . . 20

Summary . . . . . . . . . . . 25

III. Methodology . . . . . . . . . . . . 26

subjects. . . . . . . . . . . . 26

Treatment . . . . . . . . . . 28

Statistical procedure........ . . 31

IV. Analysis of Data. . . . . . . . . . 32

Results . . . . . . . . . . . . 32

Summary of Results. . . . . . . . . 41

v. Summary and Conclusions.......... . . 44

Results . . . . . . . . . . . 47

Discussion. . . . . . . . . . . . 4 47

Recommendations . . . . . . . . 50

iv 
Bibliography . . . . . . . . . . . . . 51

Appendix . . . . . . . . . . . . . . . 56

Appendix A. First Grade Pretest and Posttest,

Fourth Grade Pretest and Posttest. . 57

Appendix B. Selected Word Problems Written by

First and Fourth Grade Students. . . 66 


\section{LIST OF TABLES}

Table

Page

1. Comparison of Pretest Scores First

and Fourth Grades . . . . . . . . . 33

2. Comparison of Posttest Scores First and

Fourth Grades. . . . . . . . . . 34

3. Comparison of Pretest and Posttest Scores

First and Fourth Grades. . . . . . . 36 


\section{LIST OF FIGURES}

Figure

Page

1. Histogram for First Grade Experimental Group Pretest . . . . . . . . . . .

2. Histogram for First Grade Control Group

Posttest. . . . . . . . . . . 37

3. Histogram for Fourth Grade Experimental

Group Pretest . . . . . . . . . . . 38

4. Histogram for Fourth Grade control

Group Pretest . . . . . . . . . . 38

5. Histogram for First Grade Experimental

Group Posttest. . . . . . . . . . 39

6. Histogram for First Grade Control Group

Posttest. . . . . . . . . . . . 39

7. Histogram for Fourth Grade Experimental

Group Posttest. . . . . . . . . . . 40

8. Histogram for Fourth Grade control

Group Posttest. . . . . . . . . . . 40 
Chapter I

Introduction

The National Council of Teachers of Mathematics in its Curriculum and Evaluation Standards for school Mathematics (1989) states that, "Problem solving should be the central focus of the mathematics curriculum. As such, it is a primary goal of all mathematics instruction and an integral part of all mathematical activity" (p. 23). Although experiences in problem solving are not limited to word problems, most word problems involve problem solving. The "problem solving" sections of mathematics textbooks present word problems almost exclusively. Mathematics Unlimited (1991), in its fourth grade textbook, uses word problems in $92 \%$ of its problem solving sections. Most standardized mathematical tests use word problems to test students' problem solving skills.

Generally, children have difficulty solving word problems. The National Assessment of Educational Progress' (NAEP) Mathematical Assessments in 1973, 1978, and in 1982 found students' low performance on word problems to be the greatest area for concern (Carpenter, Lindquist, Brown, Kouba, Silver, \& Swafford, 1988). These results prompted the National Council of Supervisors of Mathematics (1978) and the National Council of Teachers of Mathematics (1980) to call for a renewed emphasis on problem solving in 
mathematics programs. Even with this emphasis on problem solving, NAEP's Fourth Mathematics Assessment, completed in 1986, reveals that problem solving continues to be an area of central concern (Kouba, Brown, Carpenter, Lindquist, Silver, \& Swafford, 1988).

Background--Previous Research

Carpenter and Moser (1984) and Decorte and Verschaffel (1987) reported that first grade students can successfully solve some word problems before being formally taught addition and subtraction. Thompson (1986), in his research with word problems, agrees that some word problems are less difficult to solve than others. He divided word problems into three different types: change problems, combine problems, and compare problems.

Change Problems (first level problems and the easiest type to solve)

The initial set is either increased or decreased to make a final set.

Example: Jan has two pencils. Barbara gives her three pencils. How many pencils does Jan then have?

Combine Problems (second level problems, harder than change

These problems involve part-whole relationships. There is one subset, the other subset and the whole set. A major difference between change and combine problems is that no action is involved in combine problems.

Example: Lisa has six buttons. Three are round, aind the rest are square. How many are square? 
Compare Problems (level three problems, the most difficult type of problem to solve)

These problems involve the comparison of distinct sets, a referent set, a compared set and a difference set.

Example: Diane has five books. Teresa has three books fewer than Diane. How many books does Teresa have?

Another way of describing word problems, based on

Greenes' et al. Techniques of Problem Solving (1981)

workbook, is by the number of steps that are involved in solving the problem.

1. A "one-step" word problem is one in which just one operation is needed to solve the problem, whether it be adding, subtracting, multiplying, or dividing.

Example: Virginia had two rings. Mary gave her three rings. How many rings does Virginia have now?

2. A "two-step" word problem is one in which two operations are needed to arrive at a solution, two equations are required to solve the problem.

Example: Kyle bought three pairs of socks for $\$ 2.00$ a pair. He gave the clerk ten dollars. How much change did Kyle get?

3. "Multi-step" word problems require three or more different operations to reach a solution. Many steps are necessary to solve the problem.

Example: The Aldrich Farm hired 6 workers to shear the trees. Each worker was paid $\$ 4.00$ per hour. Bill worked 6 hours, Jim 7.5 hours, Betty 9 hours, Tom 8 hours, Sally 4 hours, and Ron 6 hours. How much did the shearing cost?

There has been considerable research investigating why word problems are so difficult for children to solve. Paul, Nibbelink, and Hoover (1986) conducted a study to 
investigate the reason for children's difficulty with word problems. In order to determine if the trouble might lie in their inability to read the problems, a study was designed in which word problems at different readability levels were presented to third, fourth, fifth, and sixth grade students. Some problems were written at a third grade reading level, some were written at a fifth grade level, and the rest were written at a sixth grade level. The results of the study showed that the readability level of the word problems did not affect the subjects' ability to solve the problems. Publishing companies have been lowering reading levels on textbook word problems for years to no avail (Paul, Nibbelink, \& Hoover, 1986).

In another study, Cummins (1988) investigated the theory that the language used in word problems was what caused them to be difficult. The language in word problems is often ambiguous and abstract. An example of this is the following problem written in two different ways:

There are 5 birds and 3 worms. How many more birds are there than worms?

There are 5 birds and 3 worms. How many birds won't get a worm?

Cummins conducted her research with first grade children. The subjects were asked to solve word problems that were read to them. One of the conditions of the study was that the subjects were asked to repeat the problem to the 
interviewer either before or after solving it. The results showed that comprehension was influenced by the language used in the word problems.

Another way of looking at the level of difficulty in word problems is from the cognitive point of view. As a result of his studies, Jean Piaget concluded that the development of logical thinking in children occurs in stages. Children at certain stages of development have difficulty solving word problems not because of the language used in the problems, as Cummins claims, but because of the stage of logical thinking they have achieved. According to Piaget, most students in grades one through six are either in the preoperational or concrete operational stage of development. Young children in the preoperational stage of development are at a prelogical or semilogical stage. Beginning at approximately eight years of age, children tend to be concrete operational in their thinking and can think logically. Piaget states, "While the child clearly evolves logical operations, these operations are only useful in solving problems involving concrete objects and events in the immediate present" (Wadsworth, 1989, p. 96).

It is not the language that causes the difficulty in solving a word problem but the children's interpretation of the language which is governed by their stage of logical thinking. Sigel states, "For Piaget, language is the tool 
by which thoughts are expressed, having been preceded by actions which are internalized and eventually defined in verbal and symbolic forms" (Elkind \& Flavell, 1969, p. 469). Piaget further explains,

- the child begins by borrowing from this collection (language) only as much as suits him, remaining disdainfully ignorant of everything that exceeds his mental level. And again, that which is borrowed is assimilated in accordance with his intellectual structure; a word intended to carry a general concept at first engenders only a

half-individual, half-socialised preconcept (the word 'bird' thus evokes the familiar canary, etc.) (Elkind \& Flavell, 1969, p. 469).

Therefore, according to Piaget's (1968) theories, children's ability to interpret the language of word problems is effected by the stage of logical thinking they have achieved.

Carpenter and Moser (1984), in a three year longitudinal study, observed the different strategies children used when solving word problems. They wanted to investigate whether the semantic structure of word problems influences the solution strategy that children use to solve the problem. Students were interviewed three times a year in first and second grade and twice a year in third grade. Five levels of strategies were observed, ranging from an inability to solve word problems to using number facts to solve word problems. The results indicated that:

1. Students were not entirely consistent in their choice of strategies. 
2. Even when the students had acquired a more efficient strategy, they often used a less efficient one.

3. The strategy the students used seemed to be influenced by the type of problem that was presented to them.

In order to confirm Carpenter and Moser's research (1984), De Corte and Verschaffel (1987) investigated the solution strategies children used to solve word problems. A longitudinal study spanning one school year was conducted. First grade students were the subjects for the study. The strategies children used to solve word problems and how they developed during the first grade year were observed. Data on how the structure of different problems influenced the solution strategies were also collected. The study concluded that the structure of word problems influenced children's ability to solve them.

Ibarra and Lindvall (1982) investigated children's ability to solve word problems. Their subjects were 113 kindergarten students. They hypothesized that the mode of presentation of word problems would influence children's ability to solve word problems. They presented problems to children in five different modes ranging from simply reading the problem in Mode 1 to reading the problem and showing them the sets and action of the story in Mode 5. The results indicated that children's understanding of word problems can be influenced by the way the problem is 
presented to them but that some kindergarten children were unable to understand the simplest word problem regardless of the mode of presentation.

Yancey, Yancey, and Thompson (1989) conducted research to investigate whether teaching students to use diagrams in solving word problems would improve their ability to solve them. Ninety-two fourth grade students were the subjects for this study. The subjects were divided into two groups. One group was taught to draw diagrams to solve word problems. The second group was taught ten steps to follow in working word problems but without diagrams. The results showed that the group that was taught to use diagrams to solve word problems performed better on the posttest than the other group.

Graves (1978), Burns (1981), and Kennedy (1985) are advocates for using writing to help students improve their abilities in solving word problems. They propose that children who write and create their own word problems will be able to solve textbook word problems more easily. Kennedy used writing in his middle school classes. His students demonstrated understanding of mathematical concepts by writing word problems. He states, "Writing in math opens a door to awareness and understanding not just of math, but of how they think and learn" (p. 61). The California Department of Education in the Handbook for Planning and 
Effective Writing Program (1986) also suggests students

write word problems to clarify mathematical concepts and apply mathematical skills. Graves (1978) comments:

It is just beginning to be recognized that writing also contributes to learning in the field of mathematics. A great number of mathematics students consistently fail to solve problems at the point of reading. Seldom are these students in the position of writing problems, or creating the reading of mathematics. Until they work 'on the other side,' at the point of formulating examples, they will not fully understand the reading contained in mathematics $(p .8)$.

To date, the evidence for using writing as a tool in solving word problems, suggests that in writing their own word problems:

1. Children would be able to score higher on standard textbook word problems than children who did not experience writing their own word problems.

2. Children would gain a better understanding of word problems by writing them.

3. Children would be more familiar with the language of word problems by using the language to write their own word problems.

The present study was limited to investigating the effect that writing word problems had on students' performance on standard textbook word problems. First and fourth grade students were chosen as the subjects for this study so that children from two different stages of development could be observed. First grade students are encountering word problems for the first time. They are beginning writers and typically at a preoperational level of 
development. Fourth grade students have had experience with word problems and writing but not with writing word problems, and they are typically in the concrete operational stage of development.

Statement of Purpose

The purpose of this study was to compare two approaches to teaching word problems, where two groups (at the first and fourth grade levels) solved word problems through the standard california textbook curriculum method; and two groups (at the first and fourth grade levels) solved word problems through a procedure of creating and writing their own examples.

Hypotheses

1. If first grade students create and write their own word problems they will achieve higher mean scores as measured by a t-test on standard word problems than first grade students who do not create and write their own word problems but solve word problems through the standard California textbook curriculum method.

2. If fourth grade students create and write their own word problems they will achieve higher mean scores as measured by a t-test on standard word problems than fourth grade students who do not create and write their own word problems but solve word problems through the standard California textbook curriculum method. 
Chapter II

Review of the Literature

Word problems are generally considered to be more difficult for children to solve than numeric exercises. Cummins (1988) studied first grade children's responses to word problems and found that in some instances, when a problem was presented in numeric format, $100 \%$ of the children could solve it. When the same problem was presented as a word problem, only $29 \%$ of the children could solve the problem. Carpenter, et al. (1980) maintain, however, that the generalization that all word problems are difficult is inaccurate. According to the results of the Second National Assessment of Educational Progress, Mathematics Assessment (Carpenter, Corbitt, Kepner, Lindquist, \& Reys, 1980), elementary school students' performance on simple "one step" word problems was generally good, but children did have difficulty with almost every problem that could not be solved in one step. The purpose of this study was to investigate whether children who created and wrote their own word problems would have a higher mean score on solving word problems than children who did not write their own word problems. Previous Research on Word Problems

Paul, Nibbelink, and Hoover (1986) investigated whether readability affected children's ability to solve word 
problems. They conducted a study with 1,238 students in third, fourth, fifth, and sixth grades from seven schools in Iowa. The students were each given fifteen word problems to solve. The word problems were written at three levels of readability using a Harris-Jacobson Formula 2 with adjustments for vocabulary and sentence control. Following are the six test forms that were used and an example of each type of problem: 1. Low Readability--Vocabulary Control (Readability
level=3.5)

City engineers built a bridge across a little river. They needed 8 days to dig a channel for the water to flow in while the bridge was being built. 19 days more were needed for the actual construction. The finishing touches took another 5 days. It cost $\$ 4,000$ a day to work on the bridge. How much did the work cost in all?

2. Midale Readability--Vocabulary Control (Readability level=5.5)

Army engineers erected a bridge across a wide river. They needed 8 days to excavate a channel for the water to flow in while the structure was being built. 19 days more were needed for the actual construction. The finishing touches demanded another 5 days. It cost $\$ 4,000$ per day to work on the project. How much did the work cost in all?

3. High Readability--Vocabulary Control (Readability level $=6.6$ )

Army engineers erected a bridge across a rushing river. They required 8 days to excavate a channel for the water to flow in while the structure was being built. 19 days more were necessary for the actual construction. The final touches demanded another 5 days. It cost $\$ 4,000$ per day to work on the project. How much did the work cost in total? 
4. Low Readability--Sentence Control (Readability level=2.6)

A bridge was put up to go across a rushing river. It took 8 days to dig a wide ditch for the water to flow in while the bridge was being built. 19 more days were needed for the major part of the work. The finishing touches took another 5 days. It cost $\$ 4,000$ a day to work on the bridge. How much did it cost in all?

5. Middle Readability--Sentence Control (Readability level=5.5)

A bridge was erected across a rushing river. 8 days were required to dig the channel that would carry the water while the bridge was being built. 19 more days were needed for the main work. The finishing touches took 5 days extra. The work cost $\$ 4,000$ a day. How much did it cost in all?

6. High Readability--Sentence Control (Readability level $=7.2$ )

A bridge was erected to span a rushing river. It required 8 days to dig a channel for the water to flow in while the bridge was under construction. 19 more days were needed for the main part of the work. The finishing touches took an additional 5 days. If it cost $\$ 4,000$ a day to work on the bridge, how much did it cost in all? (Paul, Nibbelink, \& Hoover, 1986, p. 167).

These problems were randomly assigned to students. The results indicated that the readability level of the word problems did not affect the students' ability to solve them.

Cummins (1988) hypothesized that it is the language used in writing word problems that impedes children's understanding of them. Children can read the words, but they are not able to understand or comprehend what the problem means. She wanted to investigate whether language 
affected children's ability to solve word problems. Her study was conducted with 38 first grade students in Boulder, Colorado. Subjects were tested individually in a quiet room during school hours. They were asked to solve 18 word problems which were read to them one at a time. They were not allowed to use paper or pencil. In solving the problems, there were two conditions. In the first condition, the child was asked to solve the word problem and then recall it to the interviewer. This was the Solve-Recall condition. In the second condition, Recall-Solve, the child was asked to recall the word problem first and then solve it. The problem presentation was randomized for each child. The oral word problem session was followed by the child being given a sheet with numeric problems on it to solve. The numeric problems corresponded with the equations used in the word problems. For example, a subject was given a word problem that said: Mary had three marbles. Then Leto gave her two marbles. How many marbles did Mary have now? Then the subject was given the problem " $3+2$ " on a sheet of paper. The data indicated that there was no significant difference between the two conditions, Solve-Recall and Recall-Solve. Performance on numeric problems was consistently higher than performance on word problems. The data indicated that performance on word problems depends primarily on comprehension of the words. 
Comprehension was influenced by the language used in the text of the problem. Certain linguistic forms were difficult for children to solve. Problems that used the words "some," "altogether," or "how many more x's than y's" were often misinterpreted by the children.

Piaget (1965), in his numerous studies with children, contended that it is not the language but the underlying logic of the problem that causes the difficulty in solving word problems. Children think their own thoughts and interpret language in their own way. Their interpretations do not necessarily correspond to what the speaker had in mind. For example, in one study he conducted, he presented children with a collection of red and blue circles and red squares. There were no blue squares. He asked the question, "Are all the squares red?" Five and six year old children would generally answer, "No, because there are some red circles." In another study the children were given a collection of animals, six horses and two cows. They agreed that the cows and horses were both animals but when asked, "Are there more horses here, or more animals?", five and six year old children answered that there were more horses because there were only two cows.

Christofedes-Papert, an associate of Piaget, repeated this task but took it one step further and asked the children what they had been asked. When they were asked, 


\begin{abstract}
"Are there more horses here, or more animals?", they answered that there were more horses because there were only two cows. When they were asked, "What did I ask you?" the children replied, "You asked me if there are more horses than cows" (Duckworth, 1987, p. 23).
\end{abstract}

Piaget states:

- whether a child understands words like 'all' and 'same,' or any other words used to refer to the concept of class inclusion and similarity, whether he understands the sort of language we use to refer to the asymmetrical and transitive relation of a series, these questions which are mainly dependent on the level which he has reached in the development of operationai behavior--and that development is relatively independent of any other, because it is governed by its own laws of equilibration. We therefore say that language is not a sufficient and necessary reason for the process (Furth, 1966, p. 192).

Based on Piaget's theories, word problems should be difficult for preoperational and concrete operational students. In the preoperational stage, their thinking is semilogical or prelogical, in the concrete stage of thinking although logical operations are attained they have limitations. Wadsworth (1989), in interpreting Piaget, states:

For the most part, concrete operational children cannot yet apply logic to problems that are hypothetical, purely verbal, or abstract. In addition, they cannot correctly reason about concrete problems that involve many variables. If concrete operational children are presented with a purely verbal problem, they are usually unable to solve it correctly. If the same problem is presented in terms of real objects, they can apply logical operations and solve the problem if there are not multiple variables involved (p. 96). 
Piaget, in Genetic Epistemology (1970), describes a study that the linguist, Hermine sinclair, conducted. When she arrived in Geneva to work with Piaget, she was convinced that the operational level of children simply reflected the linguistic level they had acquired. She designed a study to test this theory. Piagetian tasks were given to the children to establish their level of logical thinking. Then two groups were formed, one group was at the preoperational stage of development and one group was at the concrete operational stage of development. The children were asked to describe different objects that were presented to them. Usually the objects were presented in pairs so the children could either describe the object by itself or compare it to the other object. She discovered that the language children used to describe the objects was quite different from the one group to the other. The preoperational group described the objects one at a time and described them one characteristic at a time. For example, "That pencil is short," "That pencil is fat." The concrete operational group described both objects together and could keep more than one characteristic in mind. An example of this was, "This pencil is longer than that one, but this one is fatter than that one." Next, the preoperational group was given linguistic training and taught to describe objects the way the concrete operational group had. After this training, 
the children were again given Piagetian tasks to determine if their level of logical thinking had changed. In every case there was only minimal progress in their level of logical thinking. Sinclair concluded that intellectual operations appear to give rise to linguistic progress, and not vice versa.

Carpenter and Moser (1984) observed that children go through specific stages when solving word problems and that these stages are influenced by the semantic structure of the word problems. They conducted a three year longitudinal study in Madison, Wisconsin, in which they interviewed 88 subjects three times in first and second grade, and twice in the third grade. The subjects were interviewed individually in a small room. Eleven trained interviewers conducted the interviews over the three year time period. Word problems were read to each child. Manipulatives were available if the subject chose to use them. The strategies which subjects used to solve word problems and how these strategies evolved over time were observed. Results indicated that there was much variability in the subjects' choice of strategy and there was no clear pattern for much of this variability. Variability was especially pronounced for combine and compare problems, indicating that the type of problem did influence the strategies used in solving word 
problems. Five levels of strategies for solving word problems were observed:

Level zero: subjects are unable to solve addition or subtraction word problems

Level one: subjects use direct modeling strategies

Level Two: subjects use direct modeling and counting strategies

Level Three: subjects use counting strategies

Level Four: subjects use number facts

These findings were confirmed by Decorte and

Verschaffel (1987). They conducted research in Belgium with 30 first grade students and found that semantic structure does influence students' abilities to solve word problems. In a longitudinal study, subjects were individually interviewed three times during one school year. During each interview, subjects were asked to solve eight word problems. The problems were read aloud to the subjects and they were asked to retell the problem, solve it, explain their strategy, build a representation of the story, and write a number sentence. From this study Decorte and Verschaffel observed three different categories of solution strategies that subjects used in solving word problems:

1. Material strategy: This is where the subject solves the problem using
manipulatives.

2. Verbal strategy: This is where the subject counts aloud when solving the problem. 
3. Mental strategy:

This is where the subject uses number facts from memory. The subject retrieves a number fact immediately from long-term memory: $5+8=13$.

on the first interview, $64 \%$ of the children used material strategies, but by the third interview $63 \%$ of the children were using mental strategies to solve word problems. These findings were consistent with the fact that the instructional program focused on learning basic addition and subtraction facts, and by the third interview the first grade subjects had received instruction in the basic facts for addition and subtraction problems with sums to 20 . The findings also indicated that the type of problem (change, combine, or compare) strongly influenced the strategies children used to solve them. Strategies to Improve student Performance on Word Problems

Current research on word problems introduces strategies that have been successful in helping students solve word problems. Ibarra and Lindvall (1982) investigated kindergarten children's abilities to solve word problems. They contended that children's ability to solve word problems could be improved by the way a problem is presented to them. They found that the majority of kindergarten children, prior to formal instruction in addition and subtraction, can comprehend some word problems and solve them by counting. In a previous study conducted in 1980, 
Ibarra and Lindvall observed that primary grade students who were successful in solving word problems had an ability to develop a physical model to serve as an aid to solution. In this 1982 study, they hypothesized that if their previous findings were correct, the number of students who could successfully solve word problems should increase if the mode of the story presentation involved more concrete aids. Different ways of presenting word problems influenced children's abilities to solve them. One hundred thirteen kindergarten students from five different schools in Pittsburgh, Pennsylvania, were the subjects for the study. In individual interviews, each subject was asked to solve thirty simple word problems. small numbers were used in the problems and no sum was above seven. The problems were presented in five different modes:

Mode 1: simply reading the problem Mode 2: reading the problem with the subject using
manipulatives

Mode 3: reading the problem and showing the sets for the story

Mode 4: reading the problem and using three sequence panels showing the action of the story

Mode 5: reading the problem and showing the sets and action of the story

Children performed poorly when the problem was presented in mode one and performed best when the problem was presented in mode five. They concluded that as the 
degree of concreteness in presenting the word problems increased, children's performance on word problems improved. They also found that $20 \%$ of these kindergarten children were unable to understand the simplest word problems even when they were presented in mode five.

Yancey, Yancey, and Thompson (1989) designed a study with a group of 92 fourth grade students Erom a rural public school in Kentucky. Half of the children were taught how to draw tabular diagrams when solving word problems; the other half were taught steps to use when solving word problems, but without diagrams. The children in the drawing diagrams group were taught to follow five steps:

1. Organize the problem data into the rows and columns of a normal spread sheet.

2. Study the relationships in the diagram (spreadsheet).

3. Decide which arithmetic operations are appropriate.

4. Compute the answer.

5. Check the answer against the diagram.

The other group was taught an eclectic approach which involved ten steps:

1. Analyzing the problem

2. Determining the wanted-given structure

3. Noting absence of essential information or presence of unnecessary data

4. Translating the problem into a number sentence

5. Defining unfamiliar vocabulary

6. Stressing logical order in setting up multi-step problems

7. Working numerous problems

8. Looking at the problem and viewing it on a smaller scale 
9. Emphasizing rereading and rechecking of
10. Domputation with a problem situation

In the study, the children received seven hours of instruction in tabular diagramming strategies or non-diagramming strategies. Even with this small amount of time, the children who were taught to draw diagrams scored higher on word problems on the posttest. The students drawing diagrams enjoyed using the new strategy they learned, and the teachers found teaching the strategies rewarding.

The studies described above have dealt with teaching children to solve word problems. Some studies have attempted to make word problems easier for children to solve by lowering the reading level of the problem, changing the language of the problems so that children can more easily understand the problems, or providing children with a more detailed presentation of the problems in order to clarify them. In other studies, children have been taught strategies to use in solving word problems. A common strand among all these studies is the children are learning more or less passively. They are being given or shown ways to solve word problems. Piaget, however, contends that in order for children to truly gain knowledge, they must be actively involved in the process. "Certainly it is only when actions 
are exercised upon objects that the logical structures are formed" (Piaget, 1968, p. 127).

Writing is a strategy that has been proposed as a valuable tool for students to use in solving word problems. It provides children with a more active approach and enables them to construct their own word problems. In Donald Graves' (1978) opinion, writing gives children a chance to actively express their ideas and feelings. By creating and writing their own problems children become familiar with the language of word problems and have less difficulty solving them.

Marilyn Burns (1981) is an advocate of children's writing of word problems. She theorizes that writing in mathematics helps children reflect on what they are doing and extends and deepens their thinking processes. In her book, A Collection of Math Lessons, she suggests that teachers provide information for students to use in writing word problems. For example, in one instance children were given the following information:

Pencils are two for 25 cents.

Erasers cost 10 cents each.

Billy has $\$ 1.00$.

Then they were asked to write questions that could be asked and answered based on that information. Once the children had made up questions they got together in small groups and 
read them to each other. Each group then shared its questions with the class. After all questions had been exhausted the children started to solve the problems. Summary

Although there are some advocates for writing word problems, research on this topic has been limited. Research that has been done involves the teacher providing outside stimulus to aid children in writing word problems. In this study students created and wrote their own word problems without being given any specific situation to write about. The research question for this thesis was, "Is there a difference in achievement in solving word problems between first and fourth grade students who have spent time creating and writing their own word problems and first and fourth grade students who have not?" 
Chapter III

Methodology

\section{Purpose}

The purpose of this study was to determine whether students who spent time creating and writing their own word problems would achieve higher scores in solving standard word problems than students who had not generated their own word problems.

Subjects

The sample for this study consisted of 59 students: 32 boys and 27 girls. Twenty-five of the students were in the first grade and the other 34 were in the fourth grade. These two grade levels were chosen because the school which agreed to participate in the study had double classes in the first and fourth grade only during the school year the study was conducted. All other grade levels had only one class. These particular grade levels also provided children at two different stages of development. First grade students are typically in the preoperational stage of development and fourth grade students tend to be at the concrete operational level of development. The students attended a private school in Los Gatos, California. They were predominantly from white, upper midale class backgrounds. Class size at this school was small. Fifteen students of the 25 first grade students were in one class, and ten students were in 
the other class. The class of 15 served as the first grade experimental group, the class of ten as the control group. Fifteen of the 34 fourth grade students were in one class, and 19 students were in the other class. The class of 19 was the fourth grade experimental group and the class of 15 was the fourth grade control group. The experimental and control groups for each grade level used the same mathematics textbook and spent the same amount of time doing mathematics each week.

Pretest

First grade subjects were given a set of 18 word problems as both a pretest and posttest. This instrument consisted of the 18 word problems used by cummins et al. (1988). Six of the word problems were change problems, such as: Joe had 3 marbles. Then Tom gave him 5 more marbles. How many marbles does Joe have now? Six of the word problems were combine problems, such as: Joe has 3 marbles. Tom has 5 marbles. How many marbles do they have together? Six of the problems were compare problems, such as: Joe has 8 marbles. Tom has 5 marbles. How many marbles does Joe have more than Tom? Because many of the first grade students were still beginning readers, the pre- and posttests were administered individually to them. The interviewer read the problem to the subjects. The subjects had a written copy of the problem in front of them so they 
could hear the problem and also see it in its written form. Manipulatives were available for the children to use in solving the problems.

The fourth grade instrument consisted of fifteen word problems taken from fourth, fifth, and sixth grade mathematics textbooks. Change, combine, and compare problems were included in the test. The fourth grade students took both the pretest and the posttest in their classrooms, working independently. The problems were not read to them. Copies of both tests appear in Appendix $A$. Treatment

The control groups included one first grade class and one fourth grade class. During the twelve week treatment time, they followed their regular mathematics program. For the first grade mathematics program a scott Foresman textbook and Mathematics Their Way (1976), an activity centered program, were used. The fourth grade mathematics program used Mathematics in our World (1983), an Addison Wesley textbook. Although word problems are included in both programs, no special emphasis was placed on tnem. In January, 1991, one first grade class and one fourth grade class participated in a twelve week experimental program. The experimental groups followed the regular mathematics curriculum but in addition they spent time creating and writing word problems in mathematics journals 
twice a week for ten minutes during their mathematics time. They then spent another ten minutes exchanging their word problems and solving them. Before the children began the program, they were not given any specific instruction on word problems or how to write them, but a group discussion was conducted. Students were asked, "Does anyone know what a word problem is?" Several children responded with their definitions of a word problem. The instructor told them, "You are going to start a mathematics journal today that you will write in every Tuesday and Thursday. In the journal you will make up and write your own word problems." Next the students were given the following instructions:

"Spend ten minutes creating and writing one or more word problems. You may write any kind of problem you want to with one restriction. You have to be able to solve the word problems you create. At the end of ten minutes, you are to choose a partner and exchange your word probiems and solve them."

During the writing time the children worked quietly and individually. At the end of the writing time, the children worked in groups of two attempting to solve the word problems their partner had written. During this time, the children were actively moving around the room and switching partners as they finished solving the word problems. Blocks and other manipulatives were available for use in solving 
the word problems as well as paper and pencils. The fourth grade students tended to use paper and pencil to solve their word problems, where the first grade students figured the problems mentally, counting on their fingers, or using manipulatives when they were stumped. If children had written unclear or unsolvable problems, it became evident at this time. Their partners would ask them for clarification of the problem and sometimes heated discussions would develop because the author of the problem usually thought the problem was perfectly clear.

\section{Posttest}

In April, 1991, after the twelve-week program, a posttest was administered to both the experimental and control groups. The instrument used was the same one used in the pretest for both the first and fourth grade groups. The first grade subjects were tested individually with the problems being read to them as before. The fourth grade subjects were tested in their classrooms working independently. The problems were not read to them. In scoring both tests $a+1$ was assigned if the answer was correct and a 0 if it was a wrong answer. No points were given for a partially correct answer.

Statistical procedure

The results of the pretest and the posttest were analyzed using t-tests for independent samples. Pretest 
mean scores for the experimental and control groups at each grade level were compared to look for any significant differences between the groups at the beginning of the treatment. Differences in posttest mean scores for experimental and control groups were statistically compared to assess the treatment effects. Means and standard deviations for all groups on both pretests and posttests are presented in tabular form, and frequency distributions are plotted.

\section{Iimitation of the study}

This study had several limitations that might affect its generalizability. All the children came from a private school in an upper middle class socio-economic area. The class sizes were small and not typical of a public school classroom. Because of the limited number of classrooms available, the classes were not picked randomly. only four classes were used in this study. Differences occurring in posttest scores could be influenced by differences in the individual teachers' teaching styles. 
Chapter IV

Analysis of Data

\section{Introduction}

The purpose of this study was to determine if creating and writing their own word problems would enhance students' ability to solve word problems. The subjects for this study were 59 elementary school children. The children were divided into four groups: one first grade experimental group, one first grade control group, one fourth grade experimental group, and one fourth grade control group. The data for this study consisted of pretest and posttest problem solving scores from all subjects.

Results

An initial pretest was administered to determine if the experimental and control groups had comparable problem solving abilities before the treatment was begun. Table 1 shows the results of the pretest for all four groups. The first grade experimental group had a mean score of 11.47 on the pretest. The first grade control group had a mean score of 10.20 on the pretest. The difference in means was 1.27 . This difference produced a $t$ value of 0.25 , a non-significant difference. The fourth grade experimental group had a mean of 6.05 on the pretest. The fourth grade control group had a mean of 5.60. The difference in means was 0.45 , a $t$-score of 0.198 , which was not significant. 
Table 1

Comparison of Pretest scores--First and Fourth Grades

\begin{tabular}{lccccc}
\hline Group & n & $\begin{array}{l}\text { Mean } \\
\text { Score }\end{array}$ & $\begin{array}{l}\text { Standard } \\
\text { Deviation }\end{array}$ & $\begin{array}{c}\text { Difference } \\
\text { in } \\
\text { Mean Scores }\end{array}$ & $\begin{array}{c}t \\
\text { Value }\end{array}$ \\
\hline $\begin{array}{l}\text { First Grade } \\
\text { Experi- } \\
\text { mental }\end{array}$ & 15 & 11.47 & 4.35 & & 0.25 \\
$\begin{array}{l}\text { First Grade } \\
\text { Control }\end{array}$ & 10 & 10.20 & 4.66 & 1.27 & \\
$\begin{array}{l}\text { Fourth } \\
\text { Grade } \\
\begin{array}{l}\text { Experi- } \\
\text { mental }\end{array}\end{array}$ & 19 & 6.05 & 2.93 & & \\
$\begin{array}{l}\text { Fourth } \\
\text { Grade } \\
\text { Control }\end{array}$ & 15 & 5.60 & 1.96 & & \\
\hline
\end{tabular}

After a twelve week period in which the experimental groups created and wrote word problems in mathematics journals twice a week, a posttest was administered to both control groups and both experimental groups. The results of the posttest are presented in Table 2. The table shows that the first grade experimental group scored a mean of 14.8 on the posttest. The first grade control group had a mean of 11.4 on the posttest. The difference in mean scores between the first grade experimental group and the first grade control group was 3.4 in favor of the experimental group. Although the experimental group had a greater increase in. 
mean scores, the difference was not statistically significant. Table 2 shows that the mean score for the fourth grade experimental group in the posttest was 8.84 . The fourth grade control group had a mean of 6.27 on the posttest. The difference in means between the two groups was 2.57 in favor of the experimental group. The fourth grade experimental group had a greater increase in mean scores from pretest to posttest, however, the t-test indicated the difference was not statistically significant. Table 2

Comparison of Posttest Scores--First and Fourth Grades

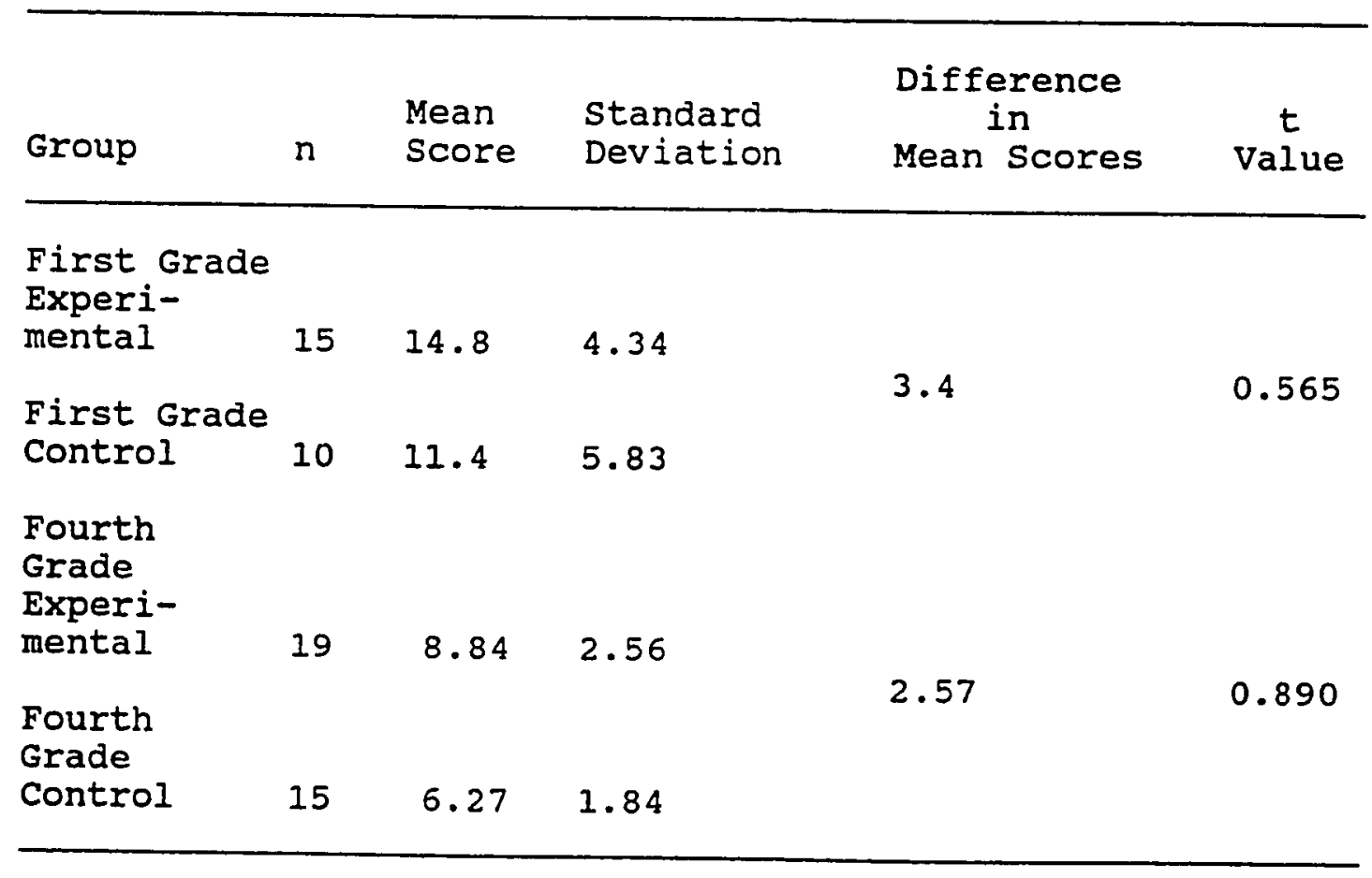

In comparing the pretest and posttest scores for each group, the mean for the first grade experimental group 
increased from 11.47 in the pretest to a mean of 14.8 in the posttest, an increase of 3.33. The mean for the first grade control group increased from a mean of 10.20 in the pretest to a mean of 11.4 in the posttest, an increase of 1.2 . The fourth grade experimental group increased from 6.05 on the pretest to 8.84 on the posttest, an increase of 2.79 . The fourth grade control group scored a 5.60 mean on the pretest and a mean of 6.27 on the posttest, an increase of 0.67 . These results are displayed in Table 3 .

Frequency distributions for pretest and posttest scores for all groups are presented in histograms in order to show a pictorial display of the patterns of scores. Figure 1 shows the range of pretest scores for the first grade experimental group. Scores ranged from +3 to +17 with a median score of 11 and a mode of 16. In Figure 2 the pretest scores for the first grade control group are presented. The scores ranged from +5 to +17 with a median of 7.5 and trimodal scores of 6,7 , and 17 . Fourth grade pretest scores are presented in Figures 3 and 4 . The fourth grade experimental group had scores ranging from +2 to +11 , with a median of 6 and a mode of 2 . The fourth grade control group had scores that ranged from +2 to +10 , with a median score of 6 and a mode of 7 .

Frequency distributions for posttest scores are displayed in Figures 5, 6, 7, and 8. The first grade 


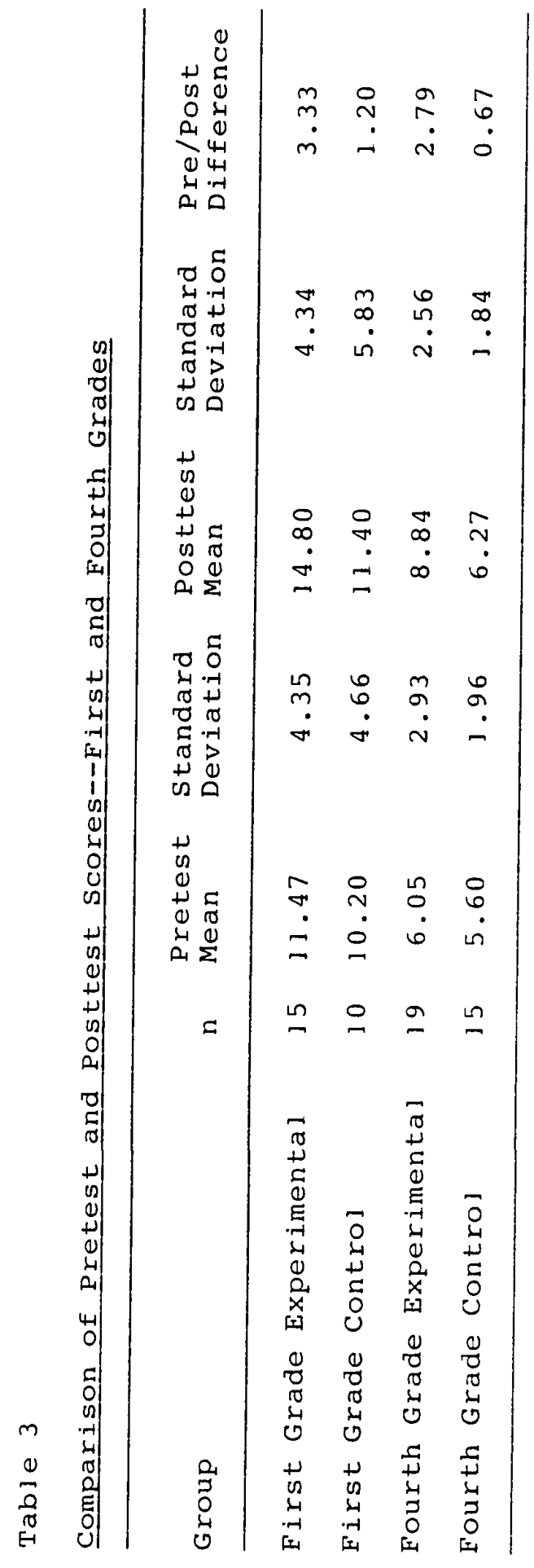


Figure 1

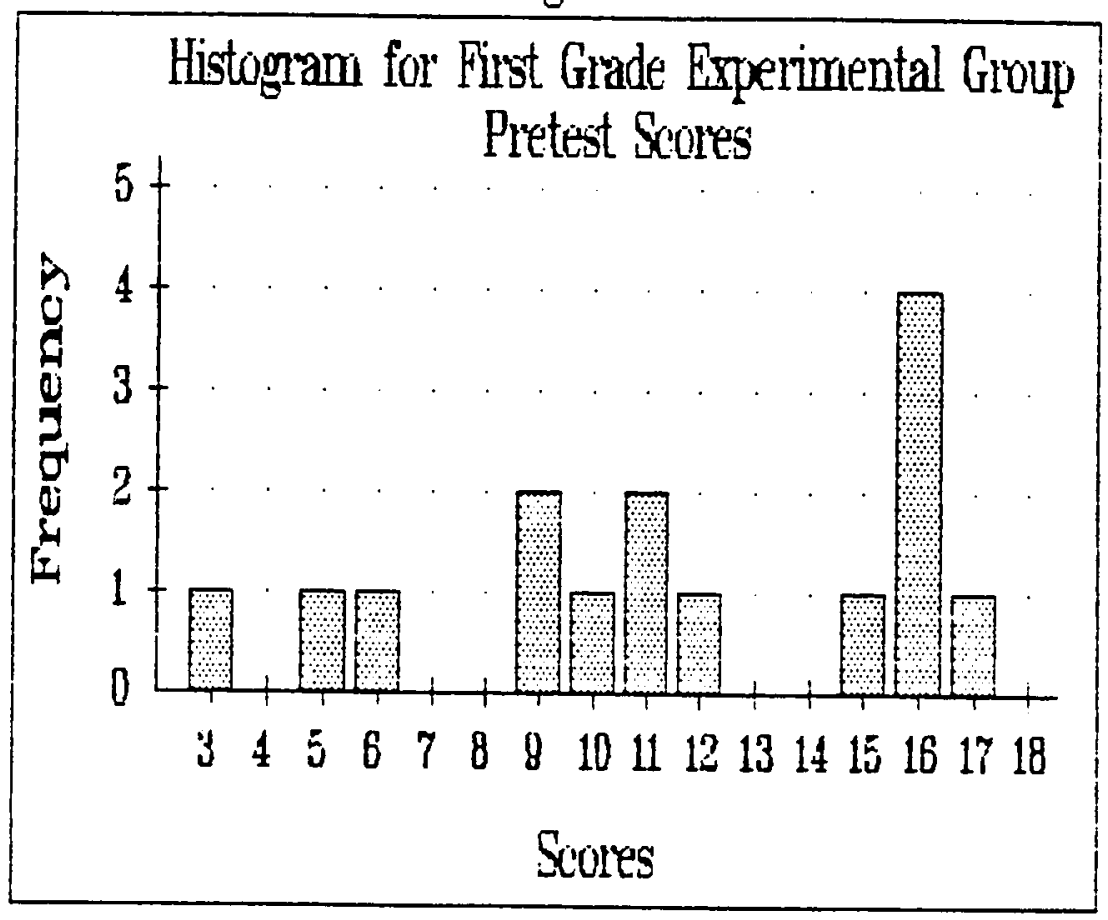

Figure 2

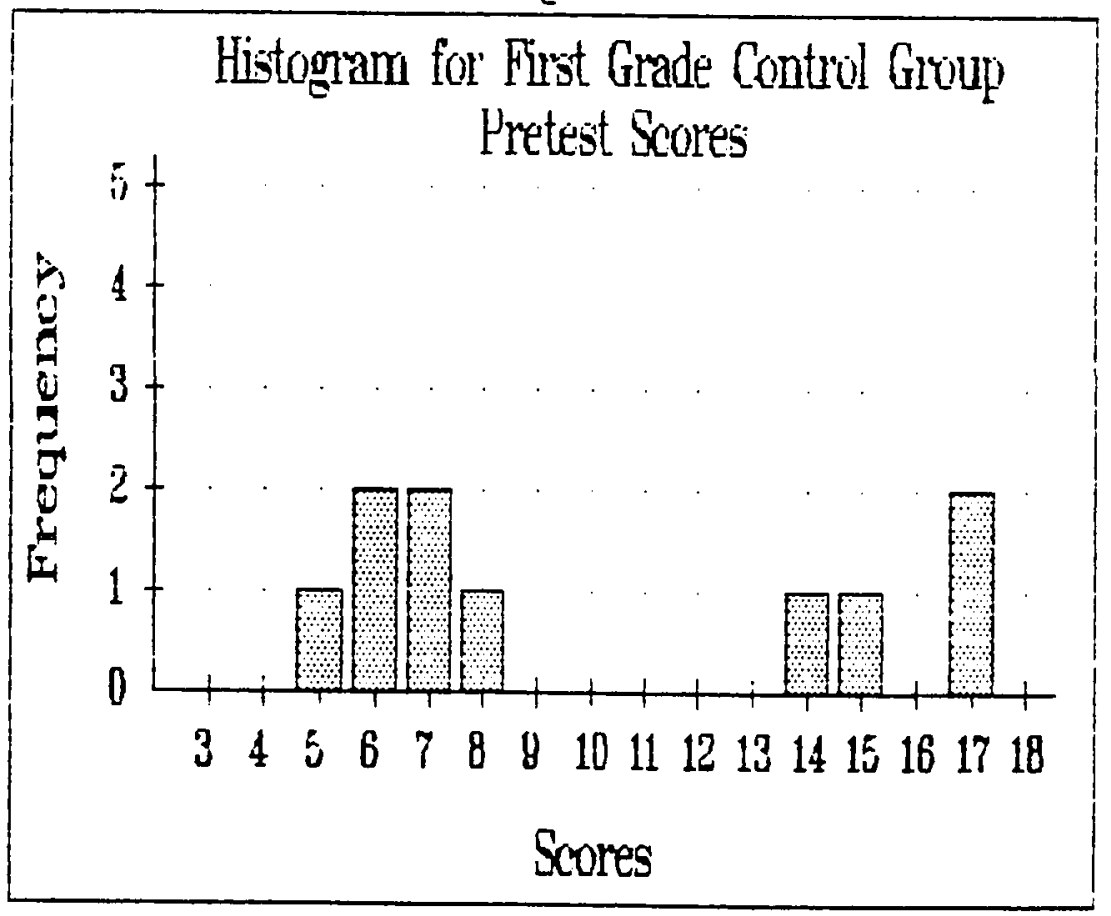


Figure 3

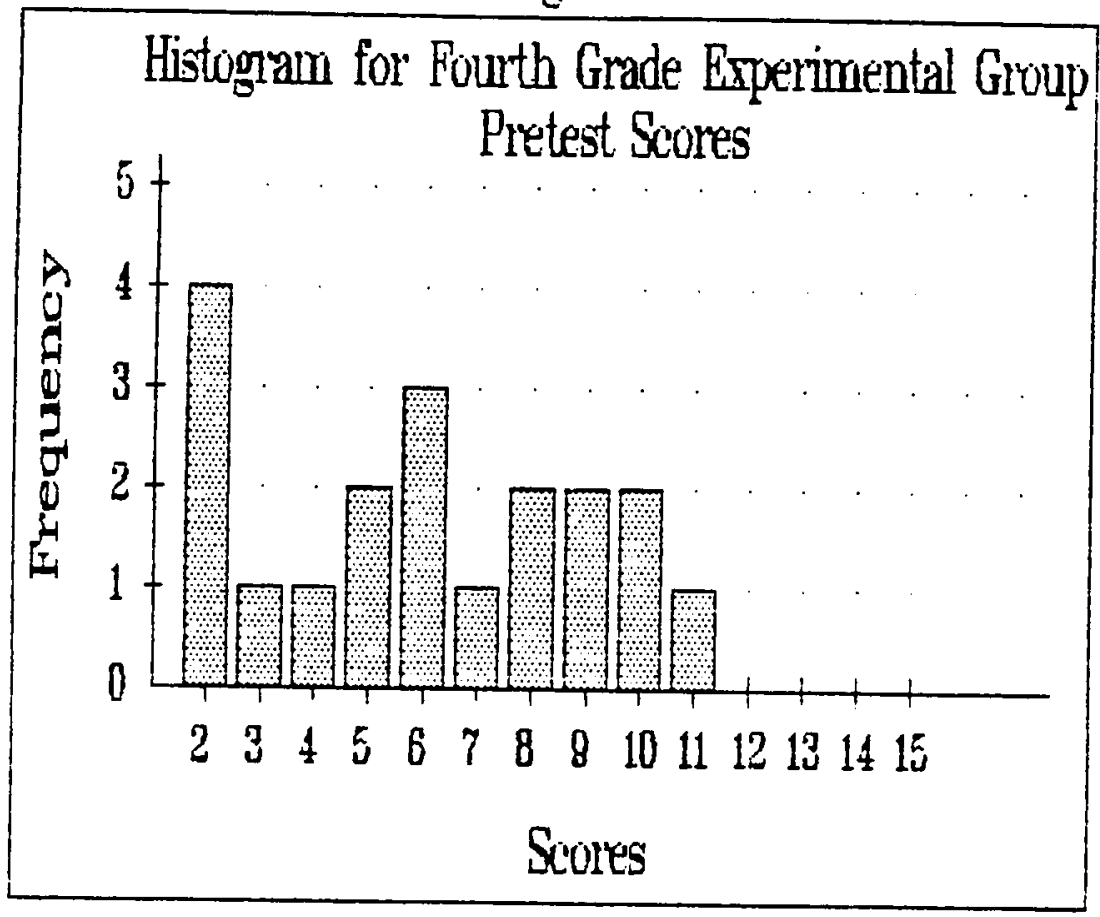

Figure 4

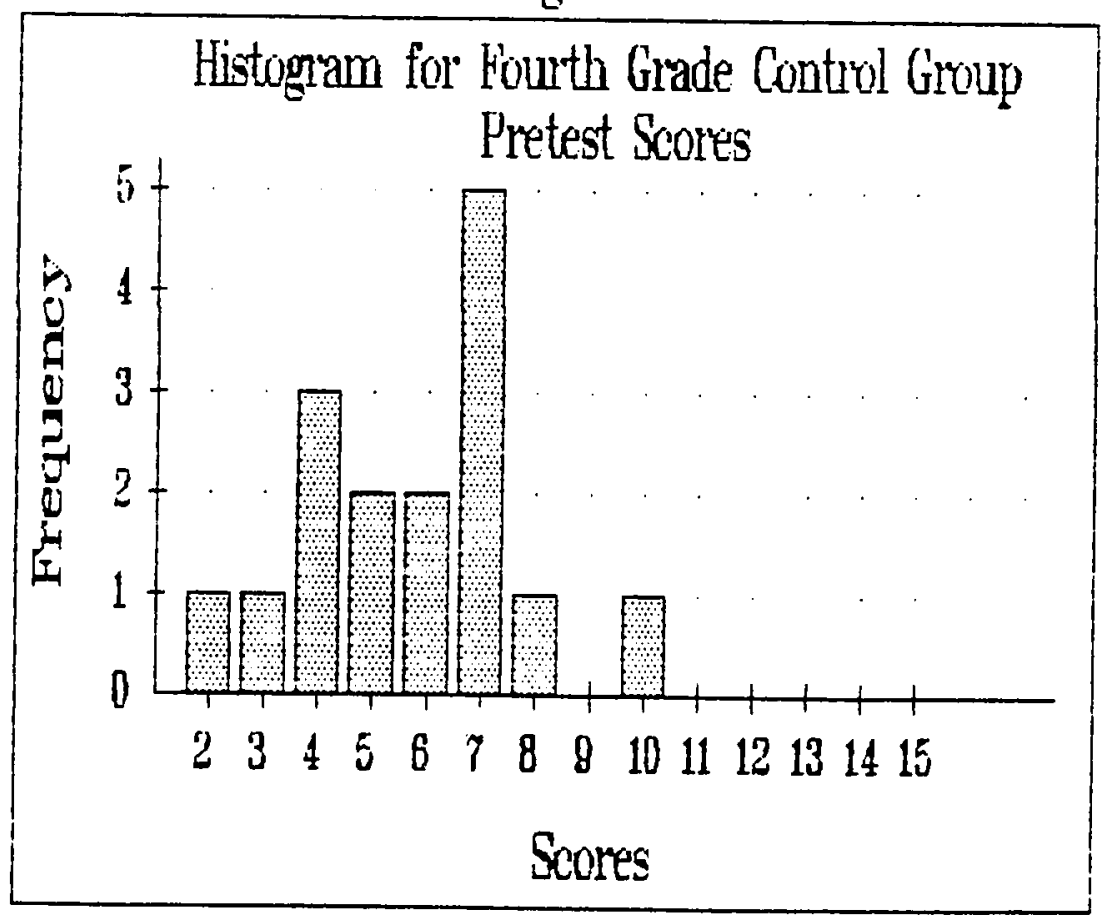


Figure 5

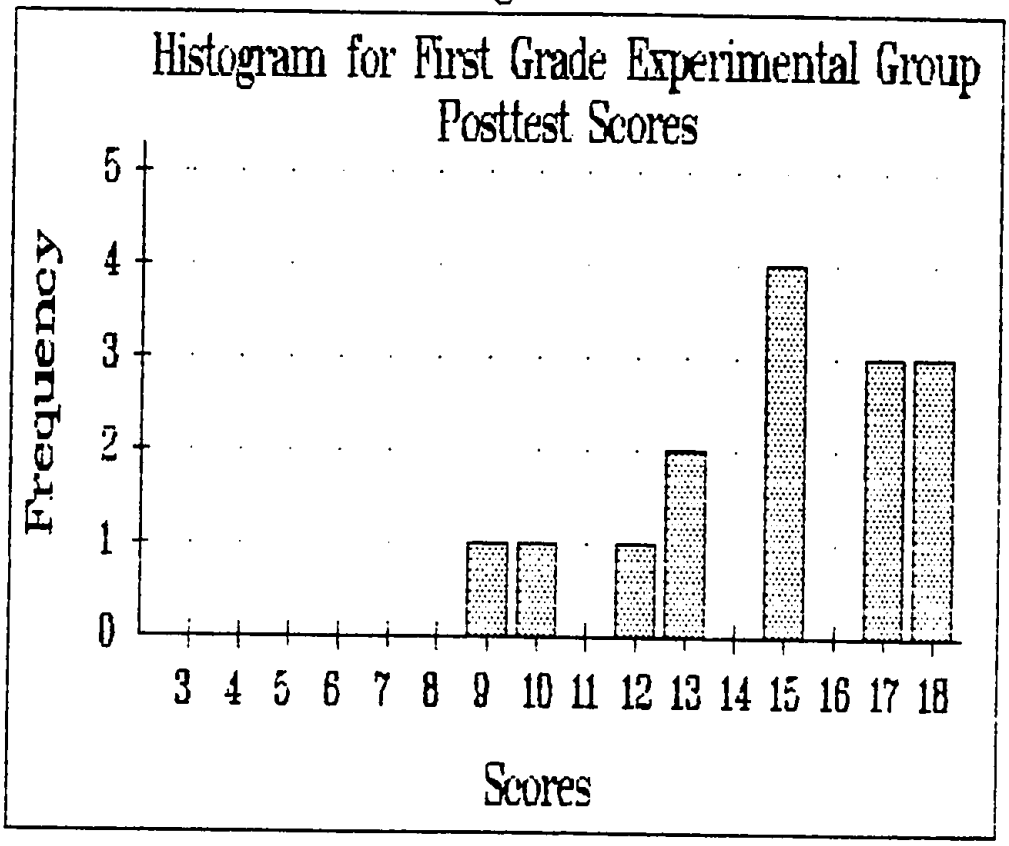

Figure 6

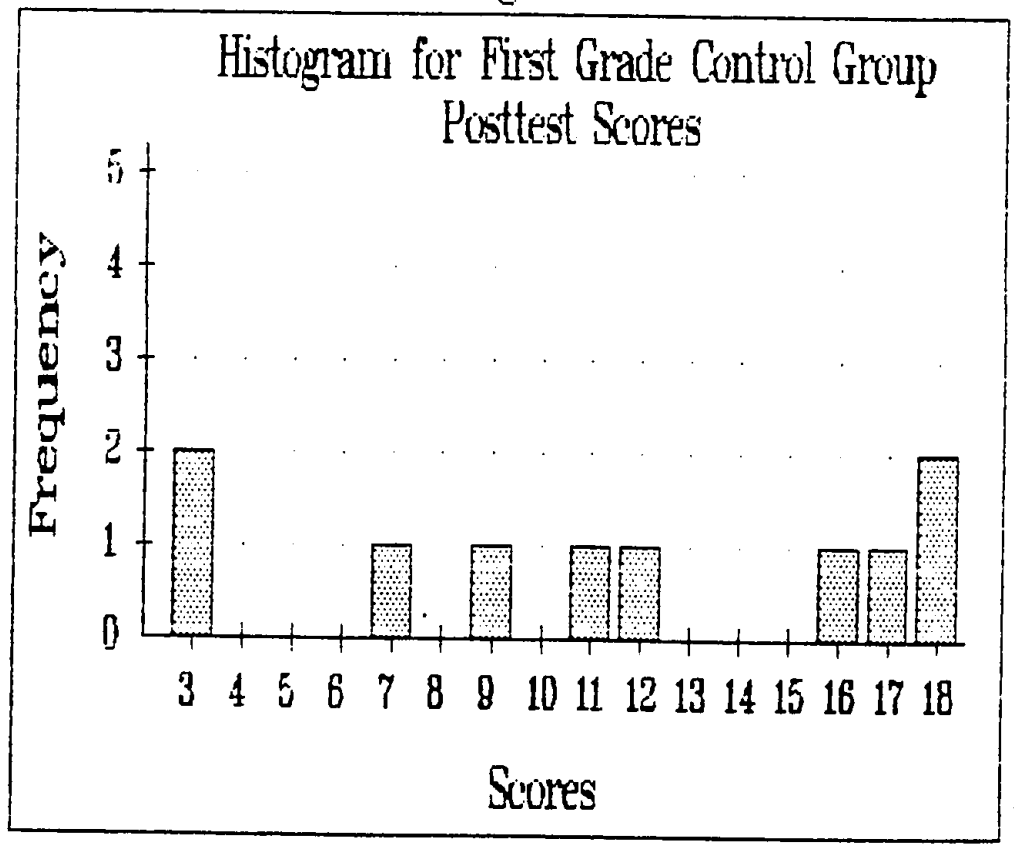


Figure 7

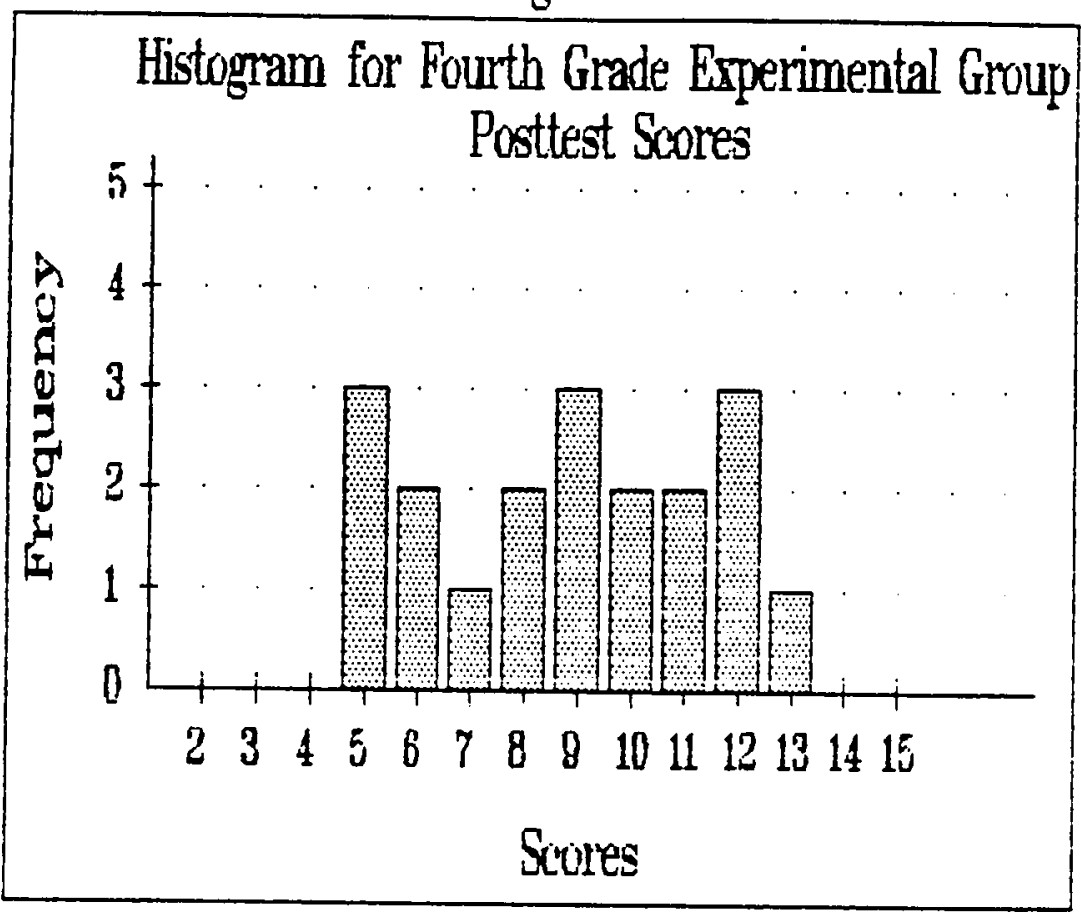

Figure 8

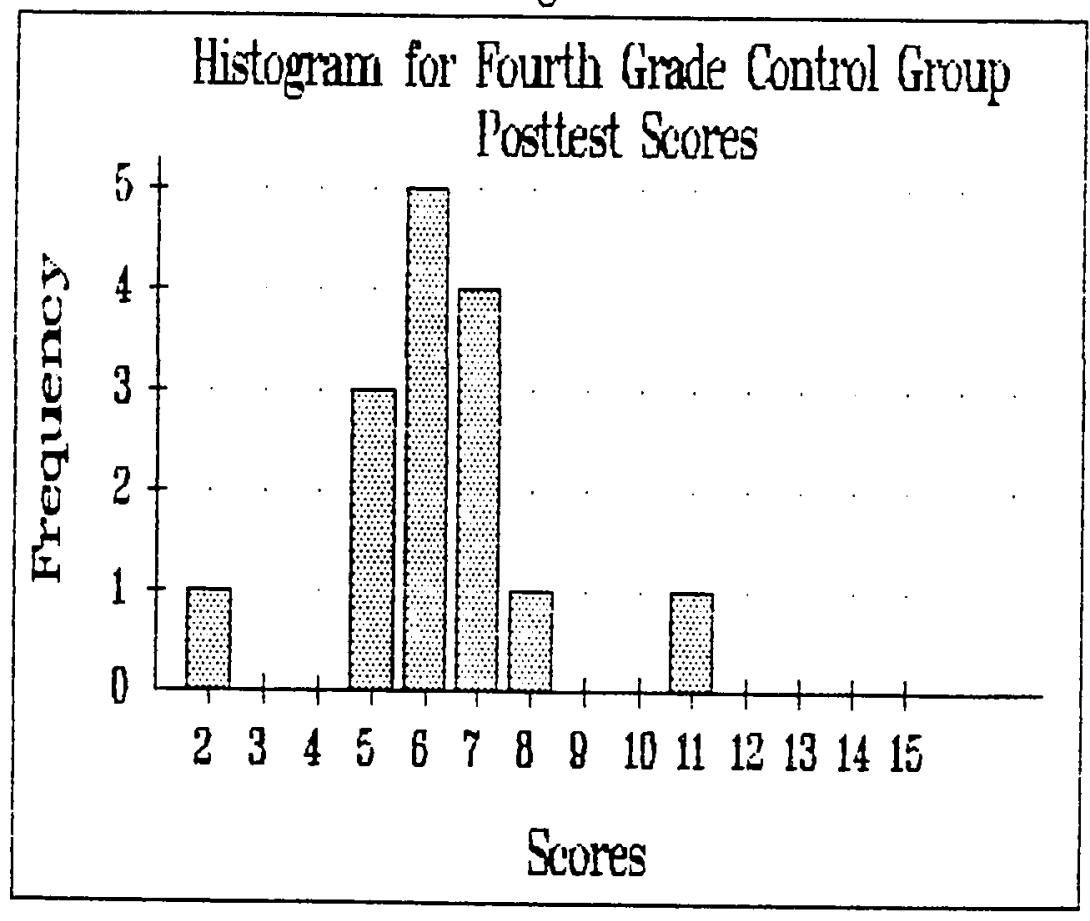


experimental group had posttest scores that ranged from +9 to +18 , with a median of 15 and a mode of 15. The first grade control group had scores ranging from +2 to +18 , with a median of 11.5 and bimodal scores of +2 and +18 . Scores for the fourth grade experimental group in the posttest ranged from +5 to +13 , with a median of 9 and trimodal scores of 5, 9, and 12. Fourth grade control group scores ranged from +2 to +11 , with a median of 6.5 and a mode of 6 . In analyzing the types of word problems written by the subjects a clear pattern is evident. The first grade subjects generally wrote change problems. Over the twelve week period, half the children wrote one or two combine problems, one third of the children wrote at least one compare problem, but the majority of the problems were change problems. Difficult problems were written by using large numbers in the problem, not by writing a more logically complicated problem.

The fourth grade subjects wrote a variety of word problems including change, combine, and compare problems. They tended to write fewer change and compare problems and more combine problems. Their problems included one step, two step, and multi-step problems.

Summary of Results

The results of this study indicated that all groups showed an increase in mean scores from pretest to posttest. 
Both experimental groups showed a greater increase in mean scores than their control group counterparts from pretest to posttest. The first grade experimental group increased 3.33 in mean scores, while the first grade control group increased 1.2 in their mean scores. Similarly, for the fourth grade groups, the fourth grade experimental group showed an increase of 2.79 in mean score while the fourth grade control showed an increase of 0.67 from pretest to posttest. These increases did not prove to be statistically significant.

The range of the scores changed from pretest to posttest. The first grade experimental group's scores were evenly distributed for the pretest, with scores ranging from +3 to +17 , but in the posttest scores were skewed to the higher end of the distribution, with scores ranging from +9 to +18 . Ten scores were +15 or above. The first grade control group's scores were clustered in two groups in the pretest, with five scores in the +5 to +8 range and four scores in the +14 to +17 range. In the posttest the scores were more evenly distributed, with scores ranging from +3 to +18. The fourth grade experimental group in the pretest had scores ranging from +2 to +11 , with a mode of +2 . In the posttest, the scores ranged from +5 to +13 , with trimodal scores of $+5,+9$, and +13 . The fourth grade control group's scores ranged from +2 to +10 on the pretest and from +2 to 
+11 on the posttest with most scores clustering around +5 to +7 in both tests.

In reviewing the type of word problem the subjects wrote, it was evident that the first grade students generally wrote change problems while the fourth grade students wrote a variety of change, combine, and compare problems. 
Chapter V

Summary and Conclusions

The purpose of this study was to determine if first and fourth grade students who created and wrote their own word problems over a twelve week period would score higher on standard word problems than first and fourth grade control groups that did not write word problems.

Word problems are difficult for students to solve, much more difficult than the same problem presented in numerical form (Cummins, 1988). Improving problem solving skills has been the goal of school mathematics for the last decade, and yet word problems are still difficult for children to solve.

Researchers have been trying to find the reason for the difficulty children have in solving word problems. Inability to read the problems was ruled out as a cause for children's difficulty by Paul, Nibbelink, and Hoover (1986). other researchers (Cummins, 1988; Decorte \& Verschaffel, 1987) found that the structure of the language used in word problems could impede children's understanding of them. Certain words or linguistic forms were often misinterpreted by children.

Piaget, in his studies with children, identified different stages of cognitive development that children pass through. The stage of cognitive development that the subjects are in would affect their ability to solve word 
problems. Children at a prelogical or concrete operational stage of development would not be able to solve abstract word problems.

Carpenter and Moser (1984) observed specific stages children go through in solving word problems and believed that the structure of word problems influenced the strategies children used in solving them.

other researchers introduced strategies to improve students' performance on word problems. Ibarra and Lindvall (1982) in their research found that the way word problems were presented to children influenced their ability to solve them. Children performed better when the presentation included not only reading the problem but showing the sets and action of the story.

Yancey, Yancey, and Thompson (1989) taught children to draw tabular diagrams when solving word problems and after only seven hours of instruction subjects who learned to draw diagrams performed better on a posttest.

In all these studies, the children were in relatively passive roles. problems were read to them, they were told to use manipulatives, to solve the problems without paper and pencil, or they received instruction on different strategies to use in solving word problems. Graves (1978), Burns (1981), and Kennedy (1985) proposed that children take 
an active role and write their own word problems as a strategy for improving their ability to solve word problems. The present study was designed to investigate whether first and fourth grade students who created and wrote their own word problems would score higher on standard word problems than students who were taught to solve word problems with the standard textbook method. Two classes of first grade students and two classes of fourth grade students served as subjects. All four groups were pretested. One first grade class and one fourth grade class participated in a twelve week long experimental condition that involved creating and writing their own word problems. After writing the problems, they exchanged the word problems with a partner and then solved them. The other first and fourth grade classes served as control groups. All groups were posttested at the end of the twelve week period. The mean scores for the pretests showed that the experimental and control groups at both levels were approximately the same in solving word problems at the beginning of the study. The mean scores for the posttest indicated that all groups improved from pretest to posttest on solving word problems. While the experimental groups' scores were higher, there were no significant differences between the experimental and control groups' scores. 
Results

This study was designed to investigate whether students would improve in their ability to solve word problems by creating and writing their own. While it cannot be concluded from this study that creating and writing word problems enables children to solve them with less difficulty, the study showed that even first grade children are capable of creating and writing their own word problems. certain behaviors which added to the value of the study were observed as the experimental groups engaged in their writing and solving of word problems. The children did not have difficulty creating word problems. They were eager to solve their partners' word problems. When the twelve weeks came to an end, the fourth grade experimental group requested that they be able to continue to write word problems in their mathematics journals. It was also interesting to note that in the posttest for the fourth grade students, all students from the experimental group attempted each problem while five of the fifteen students from the control group put question marks on problems and did not attempt to solve them.

Discussion

Previous research has not given us a definite answer to the question of why children have difficulty solving word problems. Is it the language of the problem or the level of 
logical thinking that causes the difficulty? During the first grade individual pretest screening it became evident that several children were confused by the language used in the word problems. Several subjects were unsure of the meaning of "some." One subject said, "It said Mary had some, so I think I'll give her 6." In another problem, she chose to give her 4. Neither number was associated with the numbers mentioned in the problem. Another subject correctly solved a problem where "some" was 3 . In the next two problems where "some" was used she said, "I figured out 'some' means $3, "$ and solved the problems as if "some" meant 3 both times. It was also clear that some subjects were trying to discover the logic of the word problems. While the first grade experimental group were writing their word problems, one student remarked, "I know how you can figure out if it's adding or subtracting. If it says how many left it's subtracting. If it says how many altogether it's adding."

Cummins (1988) in illustrating the ambiguous language of word problems gave the following examples:

There are 5 birds and 3 worms. How many more birds are there than worms?

There are 5 birds and 3 worms. How many birds won't get a worm?

The language in the first example is confusing to younger preoperational children. They can relate to and 
understand the second example much better. The question is why the language is difficult for children to understand. Piaget (1970) would say it is the stage of development the child is in that causes the difficulty in solving these problems. Children cannot be taught to understand the language in these questions. Interpretation of the language is governed by the child's stage of logical thinking.

The children in this study created and wrote their own word problems. This provided them with a concrete active experience in dealing with word problems. By solving each other's word problems and interacting with each other during that activity they engaged in social interaction. According to Piaget (1968), concrete experience and social interaction aid a child in moving through the stages of logical development.

Subjects' mathematics journals indicated that there was a progression from writing simple word problems at the beginning of the twelve weeks to writing more complex word problems by the end of the study. The type of word problem written by the students differed for the two grade levels. First grade children generally wrote the easiest type of problem, change problems, while the fourth grade students generally wrote combine problems, the next level problem, but not the hardest type. Samples of these word problems are (in original spelling): 
First Grade:

My dad had 8 cars. His friend bide 5. How mene wur left?

Fourth Grade:

Clare gets $\$ 16$ a month from her parents. How much money will she get for 9 months?

Further samples of first and fourth grade word problems are presented in Appendix B.

Recommendations

Recommendations for future study are:

1. This study should be conducted over a longer period of time.

2. This study should be conducted with a larger group of students from more diverse socio-economic and cultural backgrounds. 
Bibliography

51 
Bibliography

Baratta-Lorton, M. (1976). Mathematics their way. Menlo Park, CA: Addison-Wesley.

Burns, M. (1986, December). Those pesky word problems. Instructor, pp. 52-54.

Burns, M., \& Richardson, K. (1981, January). Making sense out of word problems. Learning, pp. 26-32.

Burns, M. \& Tank, B. (1988). A collection of math lessons. New Rochelle: Math Solution.

Carpenter, T. (1985) : How children solve simple word problems. Education and Urban Society, 4, 417-425.

Carpenter, T., Corbitt, M., Kepner, H., Iindquist, M. , \& Reys, R. (1980, April). Results and implications of the second NAEP mathematics assessments: Elementary school. Arithmetic Teacher, pp. 10-12.

Carpenter, T., Corbitt, M., Kepner, H., Lindquist, M., \& Reys, R. (1980, September). Solving verbal problems: Results and implications from national assessment. Arithmetic Teacher, pp. 8-12.

Carpenter, T., Fennema, E., Peterson, P., \& Carey, D. (1988). Teachers' pedagogical content knowledge of students' problem solving in elementary arithmetic. Journal for Research in Mathematics Education, 19,

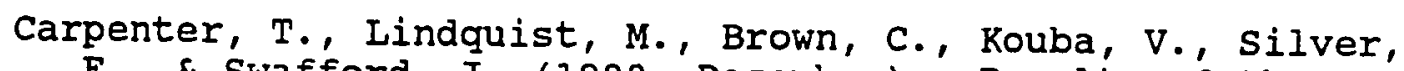
E., \& Swafford, J. (1988, December). Results of the fourth NAEP assessment of mathematics: Trends and conclusions. Arithmetic Teacher, pp. 38-41.

Carpenter, T., \& Moser, J. (1984). The acquisition of addition and subtraction concepts in grades one through three. Journal for Research in Mathematics Education, 15, pp. 179-202.

Carpenter, T., Moser, J., \& Romberg, T. (Eds.). (1982). Addition and subtraction: A cognitive perspective. New Jersey: Lawrence Erlbaum Associates. 
Christie, J., \& Noyce, R. (1989). Integrating reading and writing instruction in arades $\mathrm{K}-8$. Massachusetts: Allyn and Bacon.

Connally, P., \& Vilardi, T. (Eds). (1989). Writing to learn mathematics and science. New York: Teacher College Press.

Cummins, D., Kintsch, W., Reusser, K. , \& Weimer, R. (1988). The role of understanding in solving word problems. Cognitive Psychology, 20, 405-438.

DeCorte, E., \& Vershaffel, L. (1987). The effect of semantic structure on first graders' strategies for solving addition and subtraction word problems. Journal for Research in Mathematics Education, 18, 363-381.

Duckworth, E. (1987). The having of wonderful ideas. Columbia: Teachers college.

Evans, C. $(1984)$. Writing to learn in math. Language Arts, 61, 838-835.

Elkind, D., \& Flavell, J. (1969). Studies in cognitive development. New York: Oxford University Press.

Fennell, F., \& Ammon, R. (1985, September). Writing techniques for problem solvers. Arithmetic Teacher, pp. 24-25.

Ford, M. (1990, November). The writing process: A strategy for problem solvers. Arithmetic Teacher, pp. 35-38.

Furth, H. (1966). Thinking without language. New York: The Free Press.

Furth, H., \& Wachs, H. (1974). Thinking goes to school. New York: Oxford University Press.

Ginsburg, H. (Ed.) . (1983). The development of mathematical thinking. New York: Academic Press.

Graves, D. (1978). Balance the basics: Let them write. New York: The Ford Foundation.

Greenes, C., Immerzeel, G., Ockenga, E., Schulman, L., \& Spungin, R. (1981). Techniques of problem solving. Palo Alto: Dale seymour Publications. 
Greeno, J. \& \& Kintsch, W. (1985). Understanding and solving word arithmetic problems. Psychological Review, 92, 109129 .

Handbook for planning an effective writing program. (1986). California state Department of Education.

Ibarra, C., \& Lindvall, C. (1982). Factors associated with the ability of kindergarten children to solve simple arithmetic story problems. Journal of Educational Research, 3 , 149-155. $\frac{\text { Invitation to mathematics. (1988). Glenview, IL: Scott, }}{\text { Foresman. }}$

Kennedy, B. (1985, February). Writing letters to learn math. Learning, pp. 59-6I.

Kouba, V., Brown, C., Carpenter, T., Lindquist, M., Silver, E., \& Swafford, J. (1988, April). Results of the fourth NAEP assessment of mathematics: Number, operations, and word problems. Arithmetic Teacher, pp. 14-19.

Lindquist, M. (Ed.). (1989). Results from the fourth mathematics assessment of the national assessment of educational progress. Reston, VA: The National Council of Teachers of Mathematics, Inc.

Mahlios, J. (1988, November) . Do I add or subtract? Arithmetic Teacher, pp. 44-52.

Mathematics in our world. (1983). Menlo Paris, CA: Addison-Wesley.

Mathematics unlimited. (1991). Orlando: Harcourt, Brace, and Jovanovich.

McGehe, C. (1991, April). Mathematics the write way. Instructor, pp. 36-38.

National Council of Supervisors of Mathematics. (1978, February). Position paper on basic skills. Mathematics Teacher, pp. 147-152.

National Council of Teachers of Mathematics. (1980). An agenda for action: Recommendations for school mathematics of the 1980s. Reston, VA: Author. 
National Council of Teachers of Mathematics. (1989). Curriculum and evaluation standards for school mathematics. Reston, VA: Author.

Paul, D. Nibbelink, W., \& Hoover, H. (1986). The effects of adjusting readability on the difficulty of mathematics story problems. Journal for Research in Mathematics Education, 3, 163-171.

Piaget, J. (1970). Genetic epistemolooy. New York: Norton.

Piaget, J. (1968). Six psychological studies. New York: Random.

Piaget, J. (1965). The child's conception of number. New York: Norton.

Sowder, L. (1988). Children's solutions of story problems. Journal of Mathematical Behavior, I, 227-238.

Stiff, L. (1986, March). Understanding word problems. Mathematics Teacher, pp. 163-166.

Talton, C. (1988, September). Let's solve the problem before we find the answer. Arithmetic Teacher, pp. 40-45.

Thompson, C., \& Hendrickson, D. (1986, March). Verbal addition and subtraction problems: Some difficulties and some solutions. Arithmetic Teacher, pp. 21-25.

Threadgill-Sowder, J., \& Sowder, L. (1982). Drawn versus verbal formats for mathematical story problems. Journal for Research in Mathematics Education, 13, 324-331.

Threadgill-Sowder, J., Sowder, L., Moyer, J., \& Moyer, M. (1984). Cognitive variables and performance on mathematical story problems. Journal of Experimental Education, 4, 56-62.

Wadsworth, B. J. (1989). Piaget's theory of cognitive and affective development. White Plains, NY: Longman Inc.

Yancey, A., Thompson, C., \& Yancey, J. (1989, March). Children must learn to draw diagrams. Arithmetic Teacher, pp. 15-19.

Zweng, M. (1979, September). The problem of solving story problems. Arithmetic Teacher, pp. 2-4. 
Appendixes

56 
Appendix A

First Grade Pretest and Posttest 


\section{PLEASE NOTE}

Copyrighted materials in this document have not been filmed at the request of the author. They are available for consultation, however, in the author's university Tibrary.

58-59, First Grade Pretest and Posttest

University Microfilms International 
Fourth Grade Pretest and Postest

Tim, Jim, and Kim have 67 cassette tapes altogether. Tim has 6 more tapes than Jim, and $\mathrm{Kim}$ has 8 fewer tapes than $\mathrm{Jim}$. Kim has exactly 15 cassette tapes. How many tapes do Tim and Jim each have?

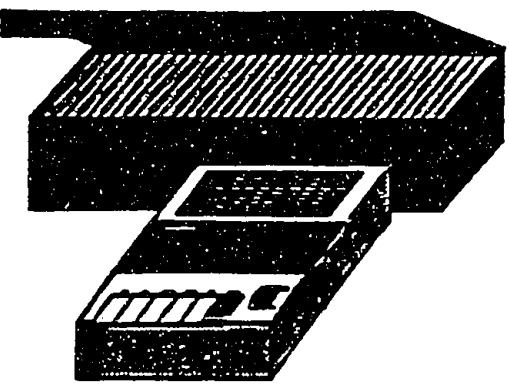

2. Can you tell who has the most tapes?

3. Can you tell who has the fewest tapes? 


\section{STIUATIOH}

Tina enjoys ristening to popular music. She usually buys her selections from a noighbortood music shop. Now, she can join a record chub and order her selections through the mail.

PROBL El. Should Tina jin the record cut?

QATA

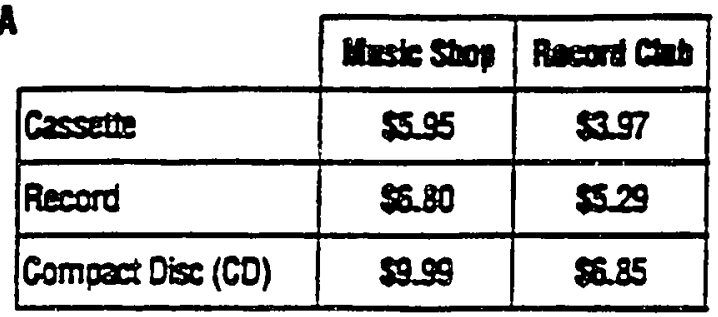

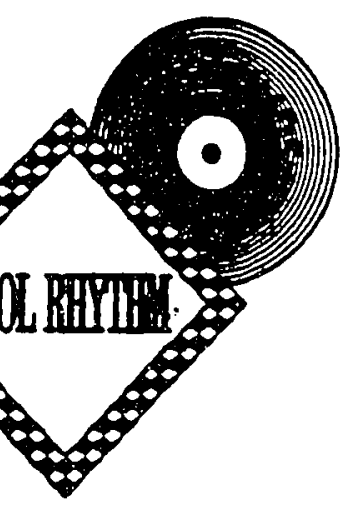

Other Factoris Record chub members must order at least 10 selections during one year.

Shipping and handling cost $\$ 1.27$ for each shipment from the record chb.

USIHE THE DATA

4 How much do 2 cassettes and $1 \mathrm{CD}$ cost at the music shop?

4. Explain.

5. How much does the same order cost from the record ctub? Explain. 
TREE FARM TRMA

6. If a tree is four years old and 2 feet in height, and It grows 1.5 feet per year. how tall will the tree be when it is 8 years old?

7. If it takes one man 2 minutes to shear a tree, how many hours will it take 3 men to shear 900 trees? 
8. The local nursery will sell tree seedlings for $\$ 30$ o hundred. or $\$ 150$ for 1,000 Frees. The Aldrich farm wants to buy 750 . Which would be the cheapect woy to purchase the trees?

9 The Aldrich Farm hired 6 workers to shear the trees. Each worker wos paid $\$ 4.00$ per hour. Bill worked 6 hours. Jim 7.5 hours. Betty 9 hours, Tom 8 hours, Solly 4 hours, and Ron 6 hours. How much did the shearing cost? 

10. Which costs more: 3 billipops thot cost 294 each, or II oummy bears that
cost 84 each? How much more? How much more?

11. Sare had three library books that were overdue. Eoch book was 9 days late. The library charges 26 a doy for lote books. How much did Sara owe the library? 
12. Carol spent $\$ 4.68,58.10$, and $\$ 6.24$

for gasoline. The tone-up cost

S22 50. Which cost more, the tane-up or the toril arount for gasoline? How mect mare?

13. New automobies are often shipped by train an special fiatears. Exch fator holds 12 ars. How many thats are needed to stup 492 new cars?

14. About 57 million Ameriean families own ars. One out of every 3 farilies owns more than I car. About how many families own more than one ar?

15. For safe driving ars should stay at lenst 1 in apart for every 3 bon per hoor of speed At least how for apart should two ars be when traveling $84 \mathrm{kon}$ per hour? 
Appendix B

Selected Word Problems Written by First Grade students 
Appendix B

Selected Word Problems Written by First Grade students (In their original spelling)

Katie has two cats. Jennifer has 11 cats. How mene all tethetr

Allibrt Instin made 30 facts he forgot 29 How many wor left? Facts And that fact was $E=m c 2$ I had 77 toys Andy had none I gave him 3 how many did I
have?

Jennifer had 30 candebars and I riped 20 of them away and then I kicked her hand and she droped 10 and I took them How wany does Jennifer have and $I$ have

Jan had 88 cents She wnt to the mall she bot a Dress the Dress cot 84 cents how much manye did she have

Nicole \& Katie \& Jeea. Went to a New Kide on the Block. constr Donee one of the New Kide kisst! Nicole. 12 times! And joe one of the New Kids to kisst Nicole 4 times how many times all togatr did Nicole get kisst. 7 people had 2 Dogs 4 people had 5 dogs how many dogs in
all? 
Selected Word Problems Written by Fourth Grade students

Karin collected 54 coins. Razzak collected 123 coins. and Mihran collected 2,051 coins. How many coins do they have together.

Billy had $\$ 17$. He gave $\$ 2$ to Matt. He got $\$ 15$ from Razzak. Gave $\$ 10$ to Karin. He got $\$ 20$ from Renee. He gave $\$ 10$ to Mihran. How much money does Billy have.

Alex wrote a report 9 pages long. Bobby wrote a report 6 times Alex's. How many pages is Bobby's report?

Arianna bought some cristals for $\$ 24$. the cristals were 4 dollars each. She also bought a magnafing glass. then she bought some candy for 50 cents they were 10 cents each. How many things did she buy.

I ate $4 / 10$ of the pie. My sister ate $3 / 8$ of the pie. How much of the pie was eaten?

There are 491 drinks and 30 people How many drinks will each person get?

Micky Mouse had 240 magic wands, Donald stole 34 , and goofy gave Micky 372 for his birthday. How many Magic wands does Micky have now? 